\title{
Bilateral cuffed tunnelled femoral dialysis catheters
}

This article was published in the following Dove Press journal: International Journal of Nephrology and Renovascular Disease 31 October 2011 Number of times this article has been viewed

\section{William T Hinchliffe Saeed Ahmed Hatem Mansy}

Department of Renal Medicine, Sunderland Royal Hospital, Sunderland, Tyne and Wear, UK
Correspondence: William T Hinchliffe Department of Renal Medicine, Sunderland Royal Hospital, Kayll Road, Sunderland, Tyne and Wear, UK SR4 7TP $\mathrm{Tel}+4401915656256$

Fax +4401915699208

Email will22@doctors.org.uk
Dialysis access remains the "Achilles heel" of maintenance hemodialysis. When candidate vessels have been exhausted in pursuit of fashioning native vascular access, alternative vessels are used. With recurrent catheter deployment, venous stenoses develop and render candidate veins unsuitable for catheter reception. We present a neat and novel solution for clinical practice in dealing with unexpected cases.

A 68-year-old female, with end-stage renal disease secondary to diabetic nephropathy had been receiving hemodialysis for 4 years. Her past medical history comprised: peripheral arterial disease with resultant bilateral above the knee amputation and iliac artery endovascular stenting; essential hypertension; lifelong tobacco consumption. She had no candidate vessels for venous catheter placement, other than small caliber femoral veins.

A decision was made to insert two smaller, more flexible 10 French catheters into bilateral femoral veins to allow better venous reception and more secure tunneling. This takes into account our experience with the use of larger, less supple catheters and the acute angles involved with typically tunneling upwards through the lower abdominal fascia. The patient was keen to continue dialysis and accepted the enhanced risk (two tunnels) of bilateral lower limb venous thrombosis and bacteremia. We present this interesting image Figure 1 (abdominal X-ray), demonstrating bilateral

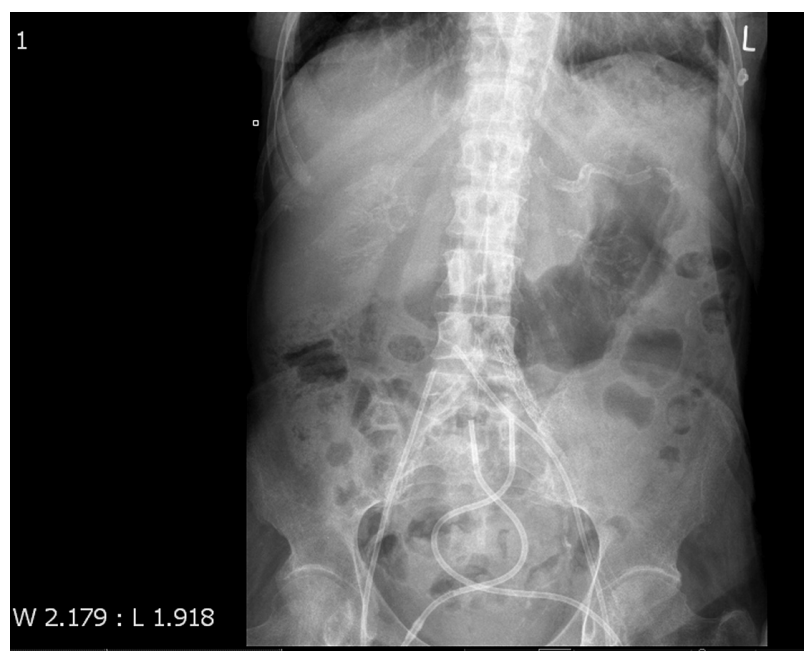

Figure I Abdominal X-ray. 
cuffed tunneled femoral dialysis access; concurrent vascular ectopic calcification and the presence of a left iliac stent. We understand this to be, the first medical image in the world literature of bilateral cuffed femoral dialysis catheters in situ - an unlikely clinical situation.

\section{Disclosure}

The authors report no conflicts of interest in this work.

\section{Publish your work in this journal}

The International Journal of Nephrology and Renovascular Disease is an international, peer-reviewed open-access journal focusing on the pathophysiology of the kidney and vascular supply. Epidemiology, screening, diagnosis, and treatment interventions are covered as well as basic science, biochemical and immunological studies. The journal welcomes original research, clinical studies, reviews \& evaluations, expert opinion and commentary, case reports and extended reports. The manuscript management system is completely online and includes a very quick and fair peerreview system, which is all easy to use. Visit http://www.dovepress.com/ testimonials.php to read real quotes from published authors.

Submit your manuscript here: http://www.dovepress.com/international-journal-of-nephrology-and-renovascular-disease-journal 